\title{
Enhancing Trade Governance Through Benchmarking Transparency Standards in Asia-Pacific Regional Trade Agreements
}

\author{
Yiying Wang and Muruga Perumal Ramaswamy \\ University of Macau, Macu SAR, China
}

\begin{abstract}
Transparency, as a fundamental principle of international trade, could reduce the cost caused by information asymmetries and promote market predictability as well as non-discriminatory treatments. This paper examines transparency provisions in both World Trade Organization (WTO) rules at the multilateral level and Asia-Pacific regional trade agreements (RTAs) at the regional as well as bilateral level. Comparing with WTO provisions, the evolving practice in Asia-Pacific RTAs successfully reinforces and deepens current multilateral transparency obligations. Besides, the importance of transparency of the preferential trade treatments is also investigated in the WTO Transparency Mechanism for Preferential Trade Arrangements. The authors argued that the homogenous content of the examined Asia-Pacific RTAs transparency development provides a governance initiative that could well offer lessons for the WTO.
\end{abstract}

\section{Keywords}

Transparency, Trade Governance, World Trade Organization, Free Trade Agreements, Regional Trade Agreements, Trade Facilitation, Preferential Trade Arrangements, APEC, Australia, China

\section{Introduction}

Transparency has been recognized as a fundamental element of good governance. In the field of international trade, it plays an important role to reduce traders' time and cost in seeking information. It also reduces information gaps that may lead to discriminatory treatments and thereby prevents potential trade disputes.

Unlike in a multilateral context, concerns of lack of transparency may not surface frequently in Regional Trade Agreements (RTAs) due to their preferential nature and mutual trust among the parties. However, this paper argues that the need for transparency in RTAs is no less significant than in the case of multilateral trade regimes. The significance of transparency in RTAs could be two fold namely its role towards fellow RTA members, and the members of the WTO. Firstly, in the context of a RTA, strong transparency standards are critical to safeguard the mutual trust among members, which is the fundamental basis of the very existence of any preferential regime. Secondly, in a multilateral context like the WTO, a clear commitment to transparency in RTAs will enhance the much-needed legitimacy any preferential treatments rendered under the auspices of the RTAs. As transparency measures play a critical role, both within and outside of any RTA, the present paper argues for the need to construct and

Copyright (C) 2015 Victoria University. This document has been published as part of the Journal of Law and Governance in both online and print formats. Educational and non-profit institutions are granted a non-exclusive licence to utilise this document in whole or in part for personal or classroom use without fee, provided that correct attribution and citation are made and this copyright statement is reproduced. Any other usage is prohibited without the express permission of the publisher. gauge transparency obligations in RTAs. In this process, it is important to ensure that the standards of transparency in RTAs are not perceived to be less than international standards. Therefore, transparency standards in RTAs have to be clearly benchmarked to enhance trade governance both at regional and multilateral level. At the multilateral level, World Trade Organization (WTO) has established a 
range of transparency standards across different agreements and mechanisms, which could potentially act as benchmarks for regional trade agreements (RTAs).

Transparency standards in WTO mechanism are found at different layers. The basic obligation on transparency as enshrined in the General Agreement on Tariffs and Trade (GATT) has inspired various transparency provisions across different WTO agreements and mechanisms. Transparency provisions governing multilateral trade obligations are spread across various agreements. Interestingly, two separate mechanisms on transparency have been created governing RTAs and non-reciprocal Preferential Trade Arrangements (non-reciprocal PTAs). The two transparency mechanisms evidence the interest of WTO members in seeking transparency in reciprocal and non-reciprocal free trade agreements. In the context of multilateral trade, the GATT Article X prescribes the fundamental transparency obligation that requires members to disclose trading information properly to enhance regulation and administration transparency. As tariff barriers go down globally, transparency and relevant procedural issues have a greater significance in behind-border measures to facilitate trade like market access, export and import administrations, standard recognition etc. Article X has further expanded in other WTO agreements and mandated to the 2013 agreed WTO Trade Facilitation Agreement (TFA). ${ }^{1}$ In the TFA, transparency measures require member countries to undertake a more comprehensive reform in trade governance than those prescribed in the GATT.

On the other hand, a large number of RTAs ${ }^{2}$ have been adopted in recent years to make bolder and faster strides. Particularly, Asia-Pacific ${ }^{3}$ marks a very active geographical area in RTAs. Among current binding RTAs, nearly one out of three involves an Asia-Pacific country. ${ }^{4}$ Meanwhile, trading powers such as Australia, China as well as regional institutions like Asia-Pacific Economic Cooperation (APEC), are located in this area. This paper investigates current transparency mechanisms in WTO multilateral regulations and regional trade agreements adopted in Asia-Pacific area, and particularly those signed by trading powers in this region, like Australia and China. The terms RTAs and free trade agreements (FTAs) refer to regional or bilateral trade agreements that are differentiated from WTO agreements at the multilateral level, and the two terms are used interchangeably in this paper. Similarly, the regional or bilateral trade agreements are sometimes referred as preferential trade agreements (PTAs), which need to be distinguished from non-reciprocal preferential trade arrangements (nonreciprocal PTAs) as recognized under the WTO mechanism. The non-reciprocal PTAs are mainly special trade arrangements targeting developing and least developed countries, like those arising out of the General System of Preferences (GSP) recognized under the GATT/WTO mechanism.

The second part of the paper reviews the literature on transparency and trade governance, and the third part examines and analyzes multilateral trading transparency mechanisms in the WTO context. Part IV mainly investigates transparent provisions in RTAs adopted by Australia, China and APEC Model Chapter on Transparency; and also compares them with the WTO transparency provisions. Part V illustrates the significance of transparency in the context of non-reciprocal PTAs reflected in the WTO Transparency Mechanism for non-reciprocal PTAs. The conclusion discusses how far the transparency standards in Asia-Pacific RTAs match relevant benchmarks and what can be improved in the future for better regional trade governance.

\footnotetext{
${ }^{1}$ The three mandates of Trade Facilitation Agreement are GATT Art. V on freedom of transit, Art.VIII on fees and formalities connected to importation and exportation and Art.X on publication and administration of trade regulations. ${ }^{2}$ The term "preferential trade agreement" in this paper is interchangeable with free trade agreement (FTA) or regional trade agreement (RTA).

${ }^{3}$ This paper adopts a general definition of Asia-Pacific referring to East Asia, South Asia, Southeast Asia and Oceania.

${ }^{4}$ According to the statistics from WTO RTA database, there are 74 out of 273 RTAs in force involving Asia-Pacific countries. See WTO Regional Trade Agreements Information System: http://rtais.wto.org/UI/PublicMaintainRTAHome.aspx
} 


\section{Transparency and Trade Agreements}

As the tariffs drastically decrease on a global scale, the focus of trade liberalization has switched to non-tariff barriers, which cover a wide arrange of trade measures, such as market entry procedures, standard recognition, import bans and labelling requirements. The non-tariff barriers could take complex forms and they tend to directly or indirectly undermine free trade objectives. A non-transparent trading environment can worsen this situation and increase the information asymmetries or make the trade more costly and time-consuming. In the OECD estimation, the low transparency results in the same economic cost caused by protectionism and lower the competition. ${ }^{5}$ For economic operators, transparency in trade policy can largely reduce their cost in collecting information. In the empirical research conducted by Freund and Weinhold, they found that companies with better access to information can export more, and the use of Internet on cross-border trading could reduce the exporter's cost in collecting information about overseas markets. ${ }^{6}$

The positive effect of transparency is also seen on trade growth. To investigate the influence of transparency upon trade, Helble etc empirically examined the improvement of transparency on trade flows among APEC members. The study found that such enhancement can yield substantial gains, similar to or even higher than trade liberalization in other disciplines. ${ }^{7}$ The researchers concluded that trade policy reforms should not be limited to the concerns of protectionism, but it is equally important to focus on transparency in trade measures.

Besides, institutional governance among different countries could be a unique comparative advantage, since transparency not only affects trade flow in quantity, but also in quality. Nunn illustrates that countries with more efficient and transparent institutional enforcement mechanism have more diverse goods, as the highly differentiated goods rely more upon predictable enforcement mechanisms. ${ }^{8}$

From the trade relations perspective, transparency is one variable in facilitating trade cooperation among governments. In the examination of the trading partners of European Union (EU) FTAs, it is revealed that countries with greater political and economic transparency tend to have a smoother negotiation process and more flexible trading arrangements in FTAs with EU. ${ }^{9}$ Moreover, less transparent trade governance has higher incidence of involvement in trade disputes. In the research on WTO disputes alleging the violation of transparency obligations, Ala'i demonstrates that WTO complaints have invoked the defendant's non-compliance with publication or due process commitments. ${ }^{10}$ In the dispute settlement interpretations on transparency, the author observed the development of transparency from a "subsidiary" to "substantive" issue. Thus, improving trade transparency is also important to avoid potential trade disputes.

Transparency has been widely recognized in trade regulations and present literature. But the definition term is often vague and subjected to diverse interpretations. It refers to different components, such as "right to know", "good governance"12 and the definitions of Transparency in the WTO mechanism

\footnotetext{
${ }^{5}$ L Patrick and R Lattimore, 'Protectionism? Tariffs and Other Barriers to Trade' in International Trade: Free, Fair and Open?, OECD, 2009,p 56.

${ }^{6} \mathrm{C}$ Freund and D Winhold, 'The Effect of the Internet on International Trade', (2004) 62 Journal of International Economics, p 171-89.

${ }^{7}$ M Helble, B Shepherd and S Wilson, 'Transparency and Trade Facilitation in the Asia Pacific: Estimating the Gains from the Reform', in Mimeo (Eds), World Bank Development Research Group, 2008,p 40.

${ }^{8}$ N Nunn, 'Relationship-Specificity, Incomplete Contracts, and the Pattern of Trade', Quarterly Journal of Economics 2007,122 (2),p 569-600

${ }^{9}$ L Baccini, 'Cheap Talk: Transaction Costs, Quality of Institutions, and Trade Agreements' (2014) 20 European Journal of International Relations, $\mathrm{p} 113$

${ }^{10} \mathrm{P}$ Ala'I, 'From the Periphery to the Center? The Evolving WTO Jurisprudence on Transparency and Good Governance' (2008) 11 Journal of International Economic Law, p 779-802.

${ }^{11}$ Joseph E. Stiglitz, "On Liberty, the Right to Know, and Public Discourse: The Role of Transparency in Public Life" (1999) Oxford Amnesty Lecture, p 27.

${ }^{12}$ Friedl Weiss, "Transparency as an Element of Good Governance in the Practice of the EU and the WTO: Overview and Comparison"(2007) 30 Fordham International Law Journal, p1545-86.
} 
are quite diverse. In the WTO's glossary, the term is defined in the context of information disclosure, as "the degree which trade policies and practices, and the process by which they are established, are open and predictable." ${ }^{13}$ The WTO Analytical Index further refers it as the obligation to notify. ${ }^{14}$ While Committee on Trade and Environment connects it directly with trade governance, saying "support the proper functioning of the multilateral trading system, by helping to prevent unnecessary trade restriction and distortion from occurring, by providing information about market opportunities and by helping to avoid trade disputes form arising." 15 Within WTO framework, transparency has several dimensions and it is further categorized into internal and external transparency by Friedl Weiss. The former refers to equal access to WTO negotiations and decision process, while the external dimension means public access to information on trading rules, procedures and decisions. ${ }^{16}$

The above different definitions reveal the dynamic nature of the components of trade-related transparency. Therefore, in order to understand the scope of transparency in trade, it is necessary to investigate the specific commitments and obligations prescribed in different contexts. The specific commitments to achieve transparency in the trade have been evolving in both multilateral trade agreements and RTAs. Particularly, how transparency obligations are manifested in multilateral trade agreement and how RTAs in Asia-Pacific have reinforced these aspects, will be discussed in the following two sections.

\section{Transparency in the World Trade Organization}

This part mainly analyzes GATT Article X and its further developments under other WTO agreements. Distinct transparency provisions in range of WTO agreements like General Agreement on Trade in Services (GATS), Trade Related Intellectual Property Rights (TRIPS) Agreement, Agreement on the Application of Sanitary and Phytosanitary Measures (SPS), Agreement on Technical Barriers to Trade (TBT), Agreement on Subsides and Countervailing Measures (SCM), and Trade Facilitation Agreement (TFA) are examined. The role and significance of WTO transparency mechanisms for PTAs is addressed subsequently in Part V.

\section{The Publication and Availability of Information}

Article X of GATT is the key provision governing the publication of trade regulation. It mainly contains two publication-related requirements. The obligations are (1) to publish promptly laws, regulations, judicial decisions and administrative rulings as well as all preferential trade arrangements; (2) new or more restrictive measures should be published before its enforcement. ${ }^{17}$ The Appellate Body in the USUnderwear specified the transparency obligation under Article X, should be considered as a principle in the disclosure of governmental trade acts. ${ }^{18}$ Furthermore, the scope of disclosed trade policies is not limited to the legislated sources, but also includes instruments that are issued by authoritative bodies and binding force under domestic law is not a necessary element. ${ }^{19}$ The way to implement this article

\footnotetext{
${ }^{13}$ Glossary, World Trade Organization, available at http://www.wto.org/english/thewto_e/glossary_e/glossary_e htm.

${ }^{14}$ Legal Affairs Division of World Trade Organization, WTO Analytical Index: Guide to WTO Law and Practice, Voll, Cambridge, 2012, p 300.

${ }^{15}$ This report points out the significance of transparency of domestic environmental regulations to avoid trade restrictions. See World Trade Organization, Trade and Environment at the WTO 44 (2004), available at http://www.wto.org/english/tratop_e/envir_e/envir_wto2004_e.pdf

${ }^{16}$ Friedl Weiss, "Transparency as an Element of Good Governance in the Practice of the EU and the WTO: Overview and Comparison"( 2007) 30 Fordham International Law Journal, p1545-86 at 72.

${ }^{17}$ General Agreement on Taffies and Trade, Apr. 15, 1994, WTO Agreement, Annex 1A, 1867 U.N.T.S. 187, at Art. X.

${ }^{18}$ United States - Restrictions on Imports of Cotton and Man-Made Fibre Underwear, WTO Appellate Body Report (1997) Dispute DS24, at Para. 21.

${ }^{19}$ European Communities and its Member States - Tariff Treatment of Certain Information Technology Products, WTO

Panel Report(2011) Dispute DS375, at Para. 7.1029-30.
} 
should enable governments and traders to be "acquainted" ${ }^{20}$ without "undue delay" 21 . This could be also interpreted as obligation to notify. This obligation is further developed as obligation to establish enquiry points to enhance an easier information access in TBT and GATS. ${ }^{22}$ Besides, the GATS and TRIPS enforce the protection of confidential information and legitimate interests of public and private parties in the information disclosing process. ${ }^{23}$

In the TFA, to reduce barriers produced by inefficient trade governance in the cross-border trading process ${ }^{24}$ publication of trade regulation is developed in a more detailed way. (TFA is mandated under three GATT provisions, and Article $\mathrm{X}$ was one of the three legal basses. ${ }^{25}$ ) In addition to incorporating the above-mentioned Article X requirements, Article 1 in TFA first specifies the scope of regulations to be published. Second, it obliges members to use the Internet to publish. ${ }^{26}$ The application of information and technologies greatly facilitate a low-cost and easy access to the information. In the second paragraph of Article 1, TFA recognizes this importance in requiring members to use the Internet to publish and update the listed trade measures. This is a step forward since Article X of GATT, the predecessor as well as counterparts in other WTO agreements, does not detail the means to publish the information. Third, to better facilitate the information delivery, TFA requests governments to establish enquiry points to respond to enquiries on the published information. Fourth, the TFA strengthens its monitoring by requiring members to notify how the publication and use of the Internet are implemented.

\section{Participation in Rule Making}

Beyond the access to the rules, enabling interested parties to participate into the rule-making process is another important development to enhance the transparency in trade. Involving interested parties into the rule-making process will reflect the practical needs and keep a positive information sharing between the administration and interested parties, but more importantly, it will also increase the transparency of the rule-making process and enhance the confidence in administration among traders, so as to promote the implementation.

In GATT, no obligation is specified relating to the public participation in rule making. Even Article XXII is on the consultation; the content is limited to consultations between contracting members under the circumstances of trade disputes. But under TBT and Agreement on Subsides and Countervailing Measures (SCM), commenting opportunity is provided to members or interested parties before imposing provisional measures. ${ }^{27}$ Similarly, Article 2 of TFA requires governments to provide stakeholders the opportunity and reasonable period to comment and consult in the rule-making process. The governments should regularly inform stakeholders of their plans of new measures or the proposed amendments and invite them to give comments and response on these measures.

\section{Predictability: Appeal or Review, Advance Rulings}

The predictability of rules is the third aspect of transparency in trade governance. Several WTO agreements contain recourse in implementation, like the right to review, the establishment of independent review institutions. Specifically, in Article X (3) of GATT, due process is emphasized in

\footnotetext{
${ }^{20}$ Dominican Republic - Measures Affecting the Importation and Internal Sale of Cigarettes, WTO Panel Report (2005) Dispute DS302, at Para. 7.414. Thailand - Customs and Fiscal Measures on Cigarettes from the Philippines, WTO Panel Report (2013) Dispute DS371, at Para. 7.773.

${ }^{21}$ Above n 19, at Para. 7.1074.

${ }^{22}$ Agreement on Technical Barriers to Trade, Apr. 15, 1994, WTO Agreement, 1868 U.N.T.S. 120, at Art.10.3; General Agreement on Trade in Services, Apr. 15, 1994, WTO Agreement, Annex 1B, 1869 U.N.T.S. 183 at Art. III(4).

${ }^{23}$ Above 22 at GATS Art. IIIbis; Agreement on Trade-Related Aspects of Intellectual Property Rights, Apr. 15, 1994, WTO Agreement, Annex 1C, 1869 U.N.T.S. 299, at Art.63.

${ }^{24}$ P.Sourdin and R Pomfret, Trade Facilitation: Defining, Measuring, Explaining and Reducing the Cost of International Trade, Camberley, Edward Elgar Publishing, 2012, p3.

${ }^{25}$ Above $\mathrm{n} 17$, at Art.V, VIII and X.

${ }^{26}$ Trade Facilitation Agreement, World Trade Organization, at Art.1 Para.2.

${ }^{27}$ Above n22 TBT at Art.2.10; Agreement on Subsidies and Countervailing Measures, Apr. 15, 1994, WTO Agreement, Annex 1A, 1869 U.N.T.S. 14, at Art. 17.
} 
the obligation to apply the regulations in a uniform, impartial and reasonable manner. It also requires members to provide review and correct mechanisms, such as judicial, arbitral or administrative procedures or tribunals. As trade regulations could affect or potentially affect stakeholders, the uniform, impartial and reasonable implementation manner is required $;{ }^{28}$ and alternative mechanisms to adjust should also be made available for involved parties. ${ }^{29}$ This implies that transparency has the dimension of the due process requirements. The TRIPS Agreement not only recognizes the right to review but also requires the parties to provide judicial or quasi-judicial authority as the final administrative decision on all agreement covered issues. ${ }^{30}$ TFA incorporates the above due process obligations and requires members to establish administrative or judicial review and appeal institutions for the administrative decisions in Article $4 .{ }^{31}$

In addition, TFA also contains a provision on advance rulings, which has not been addressed in GATT. Advance rulings are about how the customs administrations have to implement laws and regulations, such as tariff, value assessment of goods, and to treat imported goods. Such rulings are formal decisions with binding force issued by customs administrations at the request of traders, such as exporters or importers. Advanced ruling is a predictability and transparency enhancement mechanism to inform traders of the law enforcement information before the transactions, reduce unnecessary release and clearance delay at the border, and to ensure the predictability and consistence in the trade governance. In Article 3 of TFA, the form and time-bound issuing of the advance rulings are covered, combining with the right to review and appeal, this provision also encourages administrations to contain unsolicited information to requesters. ${ }^{32}$ Hence, TFA provisions are aimed at ensuring that the traders have access to related information and there by enhance predictability in law enforcement.

\section{Trade Related Transparency Standards in Asia-Pacific}

The proliferation of RTAs has marked Asia-Pacific an essential feature in trade governance. By 2014, a total of 119 RTAs in this region has entered into force, and 69 in negotiation. ${ }^{33}$ The aim of this part is to identify to what extent RTAs have deepened and expanded the above-mentioned three fields of multilateral transparency standards. This section examines the transparency related measures as reflected in Asia-Pacific RTAs although mainly focusing on the in Asia-Pacific Economic Cooperation (APEC) and trade agreements involving Australia and/or China.

\section{APEC Model Chapter on Transparency}

In a pursuit to enhance transparency standards in the Asia-Pacific RTAs, the APEC introduced a Model Chapter (MC) on transparency at the APEC Ministerial Meeting held at Vladivostok, Russia in September 2012. The MC is not just a model law setting transparency standards for future FTAs in Asia-Pacific but is inspired by such standards already existing in the current FTAs in the region. The Transparency $\mathrm{MC}$, albeit being a non-binding instrument, gains significance due to its unique characteristics. Firstly, in spite of being a model law, the MC is not a set of goals just built upon desirable best practices but is based upon actual practices of the APEC members under their FTAs. ${ }^{34}$ Secondly, the MC recognizes that the WTO rules on transparency are just the minimum standards and seeks to advocate further standards based on the FTAs of APEC members. Thirdly, the MC aims to use those additional transparency standards as a benchmark in order to promote a coherent and consistent approach across other FTAs.

\footnotetext{
${ }^{28}$ The three elements were interpreted as obligations by the Panel in Argentina-Hides and Leather. See Argentina Measures Affecting the Export of Bovine Hides and the Import of Finished Leather, WTO Panel Report (2001) Dispute DS155, at Para. 11.86.

${ }^{29}$ Above $\mathrm{n} 18$ at Appellate Body Report, at Para. 21.

${ }^{30}$ Above $\mathrm{n} 23$ TRIPS at Art. 62.5 .

${ }^{31}$ Above n26, at Art.4.

${ }^{32}$ Above n26, at Art.3

${ }^{33}$ Asia Development Bank, Asian Regional Integration Centre: http://aric.adb.org/fta-trends-by-status.

${ }^{34}$ It also draws its inspiration from the relevant transparency provisions of GATT and GATS under Article X and III respectively.
} 
A close examination of the MC reveals a whole array of recommended general transparency standards, which are however subjected to specific standards that may be prescribed in specialized areas of cooperation like SPS or TBT. ${ }^{35}$ In seeking higher standards of transparency the MC intends to promote due process in policy-making and facilitate the administration and exchange of information between FTA members. ${ }^{36}$ Eight concrete sets of transparency standards are prescribed by the MC and interestingly specific mention is made when a particular standard is intended to reflect the WTO transparency standard. For example, the first standard prescribed by the MC namely, 'the publication of measures of general application', is explicitly identified as a reflection of the relevant WTO standard. ${ }^{37}$ Besides, the MC requires recommends a prompt publication no later than when the measure in question becomes effective ${ }^{38}$ and suggests the provision for time in between those two acts, where practicable. Similarly, the MC also requires the publication of the 'purpose and rationale' of the adopted measures.

The next MC recommendation requiring 'public consultation' demonstrates its attempt to establish transparency standards beyond WTO. With an aim to provide opportunity for input from the other party to a FTA and its interested persons, the MC requires 'prior publication of draft measures ${ }^{, 39}$ (along with an explanation of its purpose and rationale) by the parties to FTA except in specific emergency situations ${ }^{40}$. A consultation period of not less than 30 days is prescribed. Although, there is no obligation to conform the draft measures in accordance with the input received from the consultation, the MC mandates the relevant authority to consider the comments. The MC not only creates the obligations to publish but also prescribes various modes of publication and distribution in order to discharge those obligations. While the publications could be carried out through a physical or online version of the official journal, their distribution has to be encouraged using additional means including an official website.

Another MC standard on 'disclosure of confidential information' is just a reflection of relevant WTO provisions ${ }^{41}$ limiting the obligation in circumstances affecting law enforcement or public interest or legitimate commercial interest of specific enterprises ${ }^{42}$. The next MC standard requires each party to a FTA to establish and provide information about 'contact points' to render assistance in finding and obtaining the published measures of general application. The parties are also required to ensure that the contact points so established are able to mutually coordinate and facilitate responses relating to the subject matters covered under the FTA. The MC standard on 'notification and provision of information' warrants a party to a FTA to respond to written enquiries of the other party on matters pertaining to the implementation of the FTA within a reasonable period of time ${ }^{43}$. Unlike some other obligations under the $\mathrm{MC}$, this standard only covers the enquiries by a party to the FTA and not the enquiries made by its interested persons.

\footnotetext{
${ }^{35}$ The MC recognizes the need to prevent conflict between the general and specific transparency standards (for example, sector specific transparency standards). The MC clearly indicates that the specific transparency provisions would prevail in the event of such a conflict. The scope of application of the MC is also limited to 'measures of general application', which are defined in lines with relevant provisions of the WTO Agreements like Article X of GATT and Articles III and XXVIII of GATS and includes laws, regulations, decision, judicial decisions and administrative rulings of general application pertaining to or affecting the matters covered by an FTA. See, Article 10 and Article 1 respectively of APEC Model Chapter on Transparency for RTAs/FTAs 2012 (the MC).

${ }^{36}$ Especially by requiring parties to FTAs to designate contact points to improve communication on FTA related matters. See the General considerations relevant to this Chapter and Article 6 of MC.

${ }^{37}$ Moreover, any relevant WTO obligations in this regard are not to be detracted by the prescribed publication standard under the MC.

${ }^{38}$ Enforcement of the measure before publication is prohibited except in situations of emergency. See Article 2(2) of the $\mathrm{MC}$

${ }^{39}$ Draft judicial decisions are exempted from the standard requiring public consultation, when such consultation will contravene the law.

${ }^{40}$ Above $n 35$ at Article 3 (4). Unlike the general emergency exception recognized in Article 2(2) the emergency recognized here is limited to specific circumstances involving internal security of the economy, monetary and fiscal policy, public interest, public health, commercial interest of particular enterprises, and law enforcement.

${ }^{41}$ The specific provisions are Article X of GATT and Article III bis of GATS.

${ }^{42}$ Above $\mathrm{n} 35$ at Article 5.

${ }^{43}$ Under normal circumstances, this is period prescribed as 30 days calculated from the date of the receipt of the written request. See Article 7(2) of the MC.
} 
The MC prescribes standards about 'administrative proceedings' in order to ensure that parties to a FTA administer their measures of general application in a consistent, impartial and reasonable manner. The administrative proceedings standard incorporates a range of specific obligations. Firstly, each party to a FTA is obliged to give a reasonable notice with a prescribed set of information about any proceedings to persons of other party directly affected by such proceedings. Secondly, the above mentioned persons of the other party have to be given a reasonable opportunity to be heard before any final administrative action is taken ${ }^{44}$. Finally, the parties are obliged to ensure that the procedures followed in such administrative proceedings are consistent with their domestic law.

The next major transparency standard recommended under the MC namely 'review and appeal' is also reflective of relevant WTO standards ${ }^{45}$. Each party is obliged to create and maintain independent and impartial judicial, arbitral or administrative tribunals or procedures ${ }^{46}$ to enable prompt review and correction of administrative actions regarding matters covered by the FTA. The MC mandates that the parties to the proceedings are provided with a reasonable opportunity of hearing and the ultimate decisions of the proceedings are reached based on the evidence adduced. Finally, the MC recognizes the need to implement such decisions, after possible appeal or review, in order to ensure that any resulting administrative action is indeed governed by those decisions.

\section{Transparency Measures in in Asia-Pacific RTAs}

At the regional level, the transparency standards discussed above have been examined in the context of 19 FTAs adopted by Australia and China. One common feature could be observed is that transparency requirement has been recognized as a principle like the principle of non-discrimination in the preambles. Generally, transparency measures have been established in a separate chapter governing all disciplines in the trade arrangement or in specified requirements under different trading fields, spreading out the transparency measures into obligations governing trade in goods, customs administrations or trade in services.

\section{Information Publication}

In addition to incorporating the GATT Article X obligations, RTAs also reinforced the Article Xrelated measures found in other WTO Agreements as general transparency principle applicable to all areas covered under the RTAs. For the scope of information, China-New Zealand FTA clearly refers to information relating to "laws, regulations, procedures, and administrative rulings of general application". The "administrative rulings of general application" is specified as an administrative ruling or interpretation that applies to all persons and facts (general application) ${ }^{47}$ and it excludes any such administrative or quasi-judicial decision that only applies to some particular person or circumstances (specific application). ${ }^{48}$ In addition to the scope defined in the China-New Zealand FTA, the China-Switzerland FTA requires relevant judicial decisions to be published. ${ }^{49}$

In the WTO agreements, protecting confidential information measures are mainly contained in GATS and TRIPS. But in FTAs examined in this paper, Australia-US FTA for instance, the similar measures protecting confidential information target all covered areas instead of being limited to trade in services and intellectual property trade. ${ }^{50}$ Meanwhile, it further specifies the application procedure, like submitting the written request and informing the other party, and requires receiving party institutions

\footnotetext{
${ }^{44}$ However, this obligation arises only when the time, the nature of the proceedings and the public interests permit such an opportunity for hearing. See Article 8 (1) (b) of the MC.

${ }^{45}$ See Article X of GATT and Article VI of GATS.

${ }^{46}$ In case if the procedures lack independence, the parties are obliged to ensure that such procedures are capable of at least providing an objective and impartial review. See Article 9 (1) of the MC.

${ }^{47}$ Free Trade Agreement Between The Government of the People's Republic of China And The Government of New Zealand,7 April 2008, at Art.168.

48 Above n47, at Art. 167.

${ }^{49}$ Free Trade Agreement between the People's Republic of China and the Swiss Confederation, 1 July 2014, at Art.1.5.

${ }^{50}$ Australia-United States Free Trade Agreement, 1 January 2005, at Art.22.4.
} 
to disclose only for justified purposes. This practice could also be found in ASEAN-Australia-New Zealand FTA ${ }^{51}$ and China-Switzerland FTA ${ }^{52}$.

To reduce the information gap between administrations, Australia-Malaysia FTA contains an information exchange mechanism, in the form of contact points, which is established in the field to facilitate the transparency in the implementation of sanitary and phytosaintray measure. The two governments are required to provide the contact points, the list of responsible authorities and significant changes in administration. ${ }^{53}$ The similar provisions are also included in Australia-Japan FTA on cooperation in information sharing. ${ }^{54}$

\section{Participation in Rule Making}

To enhance the transparency of the rule-making process, RTAs adopt a more open attitude to encourage affected parties as well as the public to participate in rulemaking in all sectors under the agreements. ${ }^{55}$ National treatment, the fundamental principle of international trade law, is further reflected in RTAs to request governments to ensure a fair treatment of stakeholders and opportunity to comment in the rulemaking process. This could be observed in Australia-Chile FTA ${ }^{56}$ and Australia-Japan FTA. ${ }^{57}$

\section{Predictability}

Transparency trade governance not only requires accessible regulations and the open rule-making process, a predictable enforcement of regulations is also indispensable. In addition to right to invoke dispute settlement mechanisms provided by the trade agreement, the right to review or appeal the administrative decision is also available to adjust and correct the administrative actions in FTAs.

Following the compulsory involvement of judicial or quasi-judicial in the review under Agreement on Implementation of Article VI of the General Agreement on Tariffs and Trade ${ }^{58}$ and TRIPS ${ }^{59}$, AustraliaUS FTA clearly reproduces the same as at least one level of review is needed, and judicial review shall be the final level of the administrative review. ${ }^{60}$ This could also be observed in Australian FTAs with Chile ${ }^{61}$ Malaysia, ${ }^{62}$ Japan,${ }^{63}$ and China-New Zealand FTA ${ }^{64}$.

In the case of advanced rulings, the trade facilitation tools in customs administration, it is arguable that the TFA is the one that follows the practice of RTAs in the filed. TFA was concluded at the ninth WTO Bali Ministerial Conference in 2013, while some of the RTAs examined in this paper, such as the RTAs containing advance rulings like the Australia-US FTA or China-New Zealand FTA were signed in 2005 and2008 respectively. Australia-US FTA also has detailed procedures than the TFA, which was signed subsequently, such as the elements to be included, ${ }^{65}$ and the time to issue the advance ruling after obtaining all the needed information.. ${ }^{66}$ When advance rulings are amended or revoked, the justification should be submitted. More importantly, contrasting with the TFA, the FTA extends the application to potential exporters or producers. ${ }^{67}$

\footnotetext{
${ }^{51}$ ASEAN-Australia-New Zealand Free Trade Agreement, 26 August 2014, at Charpter11, Art.13, para.8.

52 Above n49, at Art.1.6.

${ }_{53}^{53}$ Malaysia-Australia Free Trade Agreement, 1 January 2013, atArt.5.5.

${ }^{54}$ Agreement between Australia and Japan for an Economic Partnership, 15 January 2015, atArt.4.7.

${ }^{55}$ Above n54, at Art.1.4.

${ }^{56}$ Australia-Chile Free Trade Agreement, 1 January 2009, atArt.7.9.1.

${ }^{57}$ Above n 54, at Art.6.7.

${ }^{58}$ Agreement on Implementation of Article VI of the General Agreement on Tariffs and Trade 1994, Apr. 15, 1994, 1868

U.N.T.S. 201, at Art. 1.3

${ }^{59}$ Above $\mathrm{n}$ 23TRIPS at Art. 41.4.

${ }^{60}$ Above $\mathrm{n} 50$ at Art.6.4.

${ }^{61}$ Above $\mathrm{n} 56$ at Art.119.

${ }^{62}$ Above n53 at Art.9.4.

${ }^{63}$ Above n54 at Art.4.8.

${ }^{64}$ Above $\mathrm{n} 47$ at Art.170.

${ }^{65}$ Such as tariff classification, country of origin, and qualification for the originating good, see Above n 50 at Art.6.3.

${ }^{66}$ Above n26 at Art.3.1.

${ }^{67}$ Above $\mathrm{n} 50$ at Art.6.3.
} 


\section{Emerging Transparency Area in Asia-Pacific RTAs}

One essential contribution made by the RTAs to the international trade governance is to add new components, such as the anti-corruption. This issue has been addressed by different international rules under different subjects. In the relevance of corruption to trade, much empirical research has showed its distortion effect upon trade flows. ${ }^{68}$ In other words, corruption is like an invisible levy increasing the cost of the trade. Anti-corruption objective could motivate domestic reforms and promote greater transparency among trading partners' economies. It might be questionable to pursue non-trade objectives in trade, such as trade sanctions against Iran or Myanmar. However, the forum of RTAs signifies the potential to promote not only trade flows, but also measures that deter elements that affect free trade.

Historically, trade agreements have not addressed the corruption issues, and it has not been included in the WTO framework so far. Integrating the anti-corruption into transparency first originated from a United Sates FTA signed with Morocco in $2004,{ }^{69}$ and US government extends this practice to its subsequent FTAs with other trading partners. In the RTAs examined in this paper, the Australia-US FTA reflects this feature as well. ${ }^{70}$

However, in 19 examined RTAs, we only observe Australia-US FTA includes one provision on regional cooperation in combating corruption and enhancing trade. ${ }^{71}$ And the provision simply encourages two parties to cooperate in eliminating corruption so as to promote trade transparency, and does not contain further substantive arrangements and procedures. Although, they may as such be weak to fight corruption in trade governance, it serves as an emerging example to illustrate that RTAs could be a viable platform to address corruption related barriers to trade.

\section{The Need for Transparency in Preferential Trade}

The need for transparency in bilateral or regional free trade agreements is a concern not only to the parties or beneficiaries to those agreements but also non-members. Free trade agreements, being exceptions to multilateral obligations under the WTO, need to effectively embrace transparency in order to gain legitimacy among non-members and to establish its compatibility with relevant rules of exception under the WTO. The role and significance of transparency obligations may differ depending on the nature of the trade agreement in question. The role of transparency obligations under the multilateral trade agreements is to ensure that the vigor of the free trade rules is not diluted and their ultimate object or goals are not indirectly defeated due to want of transparency in the actions of member states.

The transparency obligations play a significant role in building confidence among large and diverse member states in a multilateral trade regime, where trade liberalization of individual members may mainly be driven by the binding force of the underlying free trade rules. However, in the context of bilateral or regional FTAs, the trade liberalization of individual members could be motivated by various other factors like strategic goals, bilateral cooperation, regional interests, etc. Under such circumstances, the role and significance of transparency obligations for the members of such agreements would arguably be different in comparison with the context of multilateral trade agreements. It is equally arguable that the role of transparency requirements under non-preferential PTAs would be distinct viz a viz its role in FTAs or multilateral trade agreements.

\footnotetext{
${ }^{68}$ J G Lambsdorff, ‘Corruption in Comparative Perception' (1998) 65 Economics of Corruption: Recent Economic Thought Series 81. E BnBarbier, R Damania \& D Léonard 'Corruption, trade and resource conversion' (2005) 50 Journal of Environmental Economics and Management 276. W Sandholtz \& W Koetzle, 'Accounting for Corruption: Economic Structure, Democracy, and Trade' (2000) 44 International Studies Quarterly 31. S Andersson \& P M Heywood, 'The Politics of Perception: Use and Abuse of Transparency International's Approach to Measuring Corruption' (2009) Political Studies $57,746$.

${ }^{69}$ United States-Morocco Free Trade Agreement, January 1, 2006, at Art.18.5.

${ }^{70}$ Above $\mathrm{n} 50$ at Art. 22.5 .

${ }^{71}$ Above n50 at Art.22.5.
} 
As mentioned earlier, PTAs could be either reciprocal or non-reciprocal in nature. Non-reciprocal preferential treatments are generally referred as preferential trade "Arrangements" instead of "Agreements" in the WTO regime. The foregoing analysis in this section is mainly focused on nonreciprocal PTAs distinct from the reciprocal PTAs ${ }^{72}$. In case of non-reciprocal PTAs, the concerns of lack of transparency among its members are expected to be less in comparison with reciprocal PTAs or FTAs or multilateral trade agreements. However, the need for transparency even in the cases of nonreciprocal PTAs cannot be under estimated. Firstly, countries not involved in a non-reciprocal PTA would still be interested in the transparency of such arrangements. As non-reciprocal PTAs tend to involve large concessions that are unilateral in nature and justified under various grounds of assistance or aid, non-participants would be interested in ensuring that any act or consequences in furtherance of non-reciprocal PTAs are indeed compatible with relevant rules like the WTO Enabling Clause ${ }^{73}$ and the generalized system of preferences (GSP) ${ }^{74}$ or waiver provisions ${ }^{75}$.

Secondly, the beneficiaries of a non-reciprocal PTA would equally be interested in seeking transparency in order to ensure that the state granting a preferential treatment is indeed treating all the beneficiaries equally. Although, the state granting the preferential treatment may be allowed to impose some restrictions upon specific beneficiaries ${ }^{76}$, the WTO Appellate Body held that the state has to administer the preferential treatment in a non-discriminatory manner among similarly placed beneficiaries. In a dispute with the European Communities (EC), India contended that the term 'non-discriminatory' under footnote 3 of the Enabling Clause prohibits EC from providing any differential treatment among developing countries under its GSP Scheme. The EC, on the other hand, defended its action on the ground that differential treatment of GSP beneficiaries are not prohibited as such and reasonable distinction among GSP benefeciaries could be made based on justifiable grounds like, for example, differing developmental needs among intended benefeciaries ${ }^{77}$.

The WTO Dispute Settlement Panel initially rejected the EC position ${ }^{78}$ and upheld India's contention that 'non-discriminatory' obligation under the Enabling Clause mandated identical tariff preferences under GSP schemes to all developing countries beneficiaries without differentiation except when

\footnotetext{
${ }^{72}$ For example the reciprocal agreement that is aimed at creating a Free Trade Area between Mercosur and the Republic of India in 2004 is referred as the Preferential Trade Agreement between MERCOSUR and the Republic of India 2004.

${ }^{73}$ Decision on Differential and More Favorable Treatment, Reciprocity and Fuller Participation of Developing Countries, GATT 1979.

${ }^{74}$ Under the legal authority granted by the Enabling Clause, developed countries create GSP schemes, where by preferential treatment is offered to trade originating from developing or least developed countries on a non-reciprocal basis. The Enabling Clause has also paved way for developing countries to create the Global System of Trade Preferences (GSTP), where by trade concessions are exchanged between developing countries. See UNCTAD, "Conclusion of the Sao Paulo Round of the GSTP: A Historical Achievement for South-South Economic Cooperation and Integration" Briefing Notes, UNCTAD Committee on Economic Cooperation and Integration among Developing Countries, No. 1, January 2011, pp.6. ${ }^{75}$ Apart from the GSP, preferential treatment for Least Developed Countries (LDCs) has been sought using waiver provisions under the WTO Agreement. For example, in the past the WTO General Council has granted waiver in order for the developing country members to provide preferential tariff treatment for LDCs. See WTO, Preferential Tariff Treatment for Least-Developed Countries, Decision on Waiver Adopted on 15 June 1999, WT/L/304, 17 June 1999, pp.2. See for the details of a similar waiver relating to services trade from LDCs C M Carpio and J C Mir, 'The Least-Developed Countries Services Waiver: Any Alternative Under the GATS?' (2014) 6 Goettingen Journal of International Law, 115.

${ }^{76}$ Under certain a priori conditions contemplated and recognized in the respective GSP Scheme.

${ }^{77}$ In this case, the EC argued that the needs of 12 beneficiary countries were different other developing countries including India and therefore deserved a special preference. However, the EC was found to have no established criteria of distinguishing the 12 beneficiary countries from the rest of the developing countries. See European Communities Conditions for the Granting of Tariff Preferences to Developing Countries, Report of the Panel, WT/DS246/R, 1 December 2003, at Para 4.290.

${ }^{78}$ Interestingly, the EC attempted to distinguish that the special treatment it bestowed under its Drug Arrangement Program was intended to address drug related problems faced by the 12 beneficiaries, distinct from other developing countries and India that did not face such problems. However, India counter argued that the increased market access opportunities under the Drug Arrangement Program has the potential to help resolve a large variety of development needs, which are commonly faced by India and other developing countries along with the 12 beneficiaries. See $n$ 77. at Para 4.290.
} 
implementing certain a priori limitations ${ }^{79}$ recognized in a GSP Scheme ${ }^{80}$. However, the Appellate Body subsequently reversed this conclusion reached by the Panel and held that the Enabling Clause did not preclude the granting of differential tariffs to different sub-categories of GSP beneficiaries ${ }^{81}$. It held that a preference granting country is not prohibited from limiting the benefits to specific sub-categories of GSP beneficiaries categorized under objective criteria. However, the Appellate Body categorically pronounced that the non-discriminatory obligation under the Enabling Class prohibited any discrimination among the beneficiaries that fall within a specific sub-category.

The Appellate Body held that identical treatment should be granted to all similarly situated GSP beneficiaries within a specific sub-category ${ }^{82}$. Thus, the obligation of non-discrimination in offering preferential treatment was also upheld by the Appellate body albeit in a more limited context than the one recognized by the Panel. This recognition of non-discriminatory obligation, therefore, warrants the need to promote high degree of transparency in non-reciprocal PTAs in order to enable eligible beneficiaries detect any denial of equal benefits.

The recognition of FTAs and non-reciprocal PTAs as exceptions to the multilateral obligations under the WTO regime naturally motivates the WTO members to seek transparency in the administration of those exceptions. Such motivations have resulted in the creation of two distinct framework of transparency under the auspices of the WTO that are primarily targeted at promoting transparency related to RTAs and non-reciprocal PTAs. In as much as the two frameworks seem to be primarily targeted at satisfying the WTO members regarding the legitimacy of RTAs and non-reciprocal PTAs, they are equally capable of enhancing transparency for the benefit of the respective countries involved. A closer examination of the features of WTO Transparency Mechanism for Preferential Trade Arrangements (TMPTA) introduced in 2010 and how the same has promoted transparency relating to Asia-Pacific non-reciprocal PTAs would indicate the importance and utility of WTO TMPTA.

The proposal for the TMPTA in the WTO was initially made by three developing nations namely Brazil, China and India along with the United States. ${ }^{83}$ It was finally adopted in 2010 to govern preferential trade of all forms ${ }^{84}$ and explicitly extend to all non-reciprocal preferential treatments under WTO agreements. ${ }^{85}$ Under this mechanism, the donor member shall notify WTO Secretariat and Committee on Trade and Development and provide required information about the covered instruments, like the full list of preferential tariffs. The notification obligation is further strengthened by the Secretariat's factual presentation ${ }^{86}$ Besides, the TMPTA encourages all members to publish information that should be submitted. ${ }^{87}$

\section{Conclusion}

WTO and Asia-Pacific RTAs adopt different approaches to address transparency in trade. It is an increasing trend in RTAs to clearly state transparency as its core objective. Contrastingly, GATT keeps silent on this term in its preamble, so as in Agreement on Technical Barriers to Trade (TBT) and Agreement on the Application of Sanitary and Phytosanitary Measures (SPS), while the GATS

\footnotetext{
${ }^{79}$ For example, the preference giving countries may recognize in their GSP Schemes certain a priori limitations (also referred as graduation provisions or mechanism) like setting up import ceilings to exclude imports from individual developing countries when their products concerned reach a certain competitive level in the market of the preference-giving country. See above n77. at Para 7.108.

${ }^{80}$ Above n77. at Para 7.140.

${ }^{81}$ European Communities - Conditions for the Granting Of Tariff Preferences to Developing Countries, Report of the Appellate Body, WT/DS246/AB/R, 7 April 2004, at Para 174.

${ }^{82}$ Above $n 77$ at Para 173.

${ }^{83}$ The joint proposal of these four states ultimately materialized in the creation of the WTO TMPTA Agreement in 2010.

${ }^{84}$ Comparing to 2006 Transparency Mechanism for Regional Trade Agreements, which deals with reciprocal trade agreements.

${ }^{85}$ Transparency Mechanism For Preferential Trade Arrangements, General Council Decision of 14 December

2010,WT/L/806, at Para 1. (c)

${ }^{86}$ Above $\mathrm{n} 85$ at Para 7.(c).

${ }^{87}$ Above $n 85$ at Para 23.
} 
replicates the GATT Article X and renames it as transparency. ${ }^{88}$ In GATT, transparency has been addressed in Article $\mathrm{X}$ as a means to enforce trade rules disclosure. Transparency in the WTO context is implemented in different specific circumstances than to proclaim it as an overarching objective. In RTAs, transparency is not just a provision to implement commitments between treaty parties, but more importantly an icon of a healthy environment to facilitate business. From this perspective, RTA transparency measures are connected more closely to good governance in trade.

In the RTAs we examined, one prevailing approach is to create a separate chapter on transparency, which is applicable to all measures under the RTA. These chapters are later implemented by sectorspecific transparency commitments in each sector-oriented chapters, like in arbitral proceeding, financial services, or sanitary and phytosanitary measures. Such approach facilitates interested parties to collect the needed information and at the same time enables the administrations to manage the transparency implementation well. On the other hand, the WTO way does not include a single provision or chapter to host transparency rules for all areas, but most of WTO transparency-related requirements are scattered in separate agreements, like GATT, TFA, SPS, TBT, GATS etc. But this method has advantages in addressing special needs of each trade area.

The motivation behind these RTA transparency measures is good governance, which implies that this kind of public good could also benefit non-party members, although they come from preferential arrangements between limited signatories. This further suggests that once the country implements their RTA transparency commitments, it would lower the cost of trade in general and may benefit nonmembers and future trading partners. Besides, the RTA provisions we examined have highly homogenous content, which could facilitate a large scale of convergence with other regimes. In turn, this process could enhance the consistency of RTAs with WTO rules, and avoid spaghetti bowel effect caused by different RTAs' overlapping rules on the same subject.

Meanwhile, as exceptions to multilateral trade arrangements under WTO regime, RTA should also contain transparent rulemaking and implementation process, which is important to build confidence among both the signatories and non-party traders. We particularly investigated the example of nonreciprocal PTAs under WTO monitoring mechanism to illustrate the transparency concerns on nreferential trade treatments RTAs examined in this naner have reinforced the relevance of multilateral 
